\title{
Trombophilic Screening in Young Adults with Myocardial Infarction: Utility or Futility?
}

\author{
Carmelo Buttà*1 and Giuseppe Miceli $^{2}$ \\ ${ }^{1}$ U.O.C. Cardiology, Department of Clinical and Experimental Medicine, Messina (Italy) \\ ${ }^{2}$ U.U.O.C. Internal Medicine with Stroke Care, Department of Health Promotion, Maternal and Child, of Internal and Specialized \\ of Excellence, Palermo (Italy)
}

*Corresponding author: Carmelo Buttà, U.O.C. Cardiology, Department of Clinical and Experimental Medicine, Messina (Italy)

\begin{tabular}{|c|c|}
\hline ARTICLE INFO & ABSTRACT \\
\hline Received: 豐 June 06, 2019 & Citation: Carmelo Buttà, Giuseppe Miceli. Trombophilic Screening in Young Adults with \\
\hline Published: 㓞 June 19, 2019 & $\begin{array}{l}\text { Myocardial Infarction: Utility or Futility?. Biomed J Sci \& Tech Res 18(5)-2019. BJSTR. } \\
\text { MS.ID.003229. }\end{array}$ \\
\hline
\end{tabular}

\section{Introduction}

It is widely accepted that several cardiovascular Risk Factors (RFs) contribute to the occurrence of Myocardial Infarction (MI) and most of them are frequently encountered in elderly population. However, occasionally MI can affect young subjects who do not present the abovementioned RFs. In these setting, thrombophilic mechanisms are often called into question to justify MI etiology. Thrombophilia describes an inherited or acquired condition which can increase the risk of venous or arterial thrombosis. The utility of testing for thrombophilia to guide prevention and treatment decisions is controversial [1], especially in patients with arterial thrombosis. Nevertheless, in the 1980s and 1990s thrombophilia testing became common in unselected patients and their relatives [2]. Even today, thrombophilia testes are frequently performed, particularly in young patients, with a not indifferent impact for health spending.

\section{Thrombophlic Disorders}

The most studied thrombophilic disorders in young patients with MI are: Factor V Leiden (FVL) and Factor II (FII) G20210A mutation. The relationship between FVL and risk of MI has led to conflicting results, therefore the association appears stronger in young subjects. A study by Butt et al. [3] showed that FVL was higher exclusively in MI patients younger than or equal to 50 years, with 3.9- fold higher prevalence in young patients than in patients older than 50 years and 2.7-fold higher than in age matched control subjects. A systematic review showed that FVL does not significantly correlate with MI (OR 1.26, 95\% CI 0.94 to 1.67), but the decision to include in the study young patients ( $<55$ years) contributed to make the association significant (OR 1.29, 95\% CI 1.03 to 1.61) [4]. A meta-analysis showed that FVL was not associated with MI but correlation was stronger in patients younger than 55 years of age affected by MI, ischemic stroke or complicated Peripheral Vascular Occlusive Disease (PVD) (OR, 1.37; 95\% CI, 0.96-1.97) [5]. However, the large Italian Atherosclerosis Thrombosis and Vascular Biology Study found no evidence for an association between FVL and MI at age younger than 45 years [6].

Even the relationship between the FII G20210A mutation and risk of $\mathrm{MI}$ is controversial but this association appears more solid in young population. Furthermore, Butt et al found that the prevalence of FII G20210A was higher in MI patients than in controls (OR 3.3 , 95\% CI 2.6-4), particularly in younger than 51 years (5.6fold higher than in age-matched control subjects) [3]. A study by Rallidis et al. showed that FII G20210A was more frequent in ST Elevation Myocardial Infarction (STEMI) patients $\leq 35$ years of age than in controls (OR 2.2, 95\% CI 1.1-4.2) and the risk increased substantially in presence of smoking as a RF [7]. Another study indicated that the FII G20210A was the only genetic prothrombotic $\mathrm{RF}$ associated with the risk of developing MI under the age of 36 years [8]. Finally, in the meta-analysis of Kim and Becker, the relationship between MI and FII G20210A was slightly stronger than the association with FVL (OR 1.28; 95\% CI, 0.94 to 1.73 ) and it seemed to become stronger in subjects younger than 55 years of age with MI, ischemic stroke or complicated PVD (OR, 1.66; 95\% CI, 1.13-2.46) [5]. However, the large Atherosclerosis Thrombosis and 
Vascular Biology Study among survivors of MI at age younger than 45 years did not confirm this association [6].

Merely some case reports reported Protein C (PC), Protein $S$ (PS) e Antithrombin (AT) III deficiencies in young patients with MI. Unfortunately, very few studies have investigated these thrombophilic disorders in a large population. Two studies by Rallidis et al found no difference in AT, PC, and PS plasma levels between patients with STEMI or MI under the age of 36 years and the controls $[7,8]$. Therefore, evidence for an association between deficiency of these factors and the risk of MI are inadequate.

Extensive evidence support the hypothesis that the Antiphospholipid (APL) syndrome is associated with risk of MI $[9,10]$. Since the diagnosis of the APL syndrome is possible if it is present at least one clinical criterion and one laboratory criterion [11], in our opinion, it is justified search for APL antibodies in young patients with MI without other cardiovascular RFs.

\section{Conclusion}

In conclusion, evidence about the relationship between thrombophilia and juvenile MI are still inadequate. FII G20210A and FVL are the only thrombophilic disorders that showed an association with MI in young patients although with some controversial results. Neverthless, some randomized trials conducted in patients with hyperhomocysteinemia (considered a RF for atherosclerosis) showed that reducing serum homocysteine levels through $B$ vitamins administration in patients with cardiovascular diseases does not modify prognosis $[12,13]$. Therefore, association is not synonymous of RF.

As long as some valuable trials do not demonstrate the efficacy of different therapeutic strategy (like using of anticoagulant or prolonged double anti-aggregation) in improving prognosis of MI in young population with positive thrombophilic screening, thrombophilic testing in these patients will be worthless and expensive. As things stand today, in patients with juvenil MI the only useful test that seems to be worth performing is APL antibodies test, even if MI is not a frequent event in APL syndrome [11-13].

\section{References}

1. Stevens SM, Woller SC, Bauer KA, Kasthuri R, Cushman M, et al. (2016) Guidance for the evaluation and treatment of hereditary and acquired thrombophilia. J Thromb Thrombolysis 41: 154-164.
2. Baglin T, Gray E, Greaves M, Hunt BJ, Keeling D, et al. (2010) Clinical guidelines for testing for heritable thrombophilia. Br J Haematol 149: 209-220.

3. Butt C, Zheng H, Randell E, Robb D, Parfrey P, et al. (2003) Combined carrier status of prothrombin 20210A and factor XIII-A Leu34 alleles as a strong risk factor for myocardial infarction: evidence of a gene-gene interaction. Blood 101: 3037-3041.

4. Boekholdt SM, Bijsterveld NR, Moons AH, Levi M, Büller HR, et al. (2001) Genetic variation in coagulation and fibrinolytic proteins and their relation with acute myocardial infarction: A systematic review. Circulation 104: 3063-3068.

5. Kim RJ, Becker RC (2003) Association between factor V Leiden, prothrombin G20210A, and methylenetetrahydrofolate reductase C677T mutations and events of the arterial circulatory system: A metaanalysis of published studies. Am Heart J 146: 948-957.

6. Atherosclerosis Thrombosis and Vascular Biology Italian Study Group (2003) No evidence of association between prothrombotic gene polymorphisms and the development of acute myocardial infarction at a young age. Circulation 107: 1117-1122.

7. Rallidis LS, Gialeraki A, Tsirebolos G, Tsalavoutas S, Rallidi M, et al. (2017) Prothrombotic genetic risk factors in patients with very early ST-segment elevation myocardial infarction. J Thromb Thrombolysis 44: 267-273.

8. Rallidis LS, Belesi CI, Manioudaki HS, Chatziioakimidis VK, Fakitsa VC, et al. (2003) Myocardial infarction under the age of 36: Prevalence of thrombophilic disorders. Thromb Haemost 90: 272-278.

9. Brey RL, Abbott RD, Curb JD, Sharp DS, Ross GW, et al. (2001) Beta(2)Glycoprotein 1-dependent anticardiolipin antibodies and risk of ischemic stroke and myocardial infarction: The Honolulu heart program. Stroke 32: 1706.

10. Zuckerman E, Toubi E, Shiran A, Sabo E, Shmuel Z, et al. (1996) Anticardiolipin antibodies and acute myocardial infarction in nonsystemic lupus erythematosus patients: A controlled prospective study. Am J Med 101: 381-386.

11. Keeling D, Mackie I, Moore GW, Greer IA, Greaves M (2012) Guidelines on the investigation and management of antiphospholipid syndrome. $\mathrm{Br}$ J Haematol 157: 47-58.

12. Armitage JM, Bowman L, Clarke RJ, Wallendszus K, Bulbulia R, et al. (2010) Effects of homocysteine-lowering with folic acid plus vitamin B12 vs placebo on mortality and major morbidity in myocardial infarction survivors: A randomized trial. JAMA 303: 2486-2494.

13. Ebbing M, Bleie O, Ueland PM, Nordrehaug JE, Nilsen DW, et al. (2008) Mortality and cardiovascular events in patients treated with homocysteine-lowering B vitamins after coronary angiography: A randomized controlled trial. JAMA 300: 795-804. 


\section{ISSN: 2574-1241}

DOI: 10.26717/BJSTR.2019.18.003229

Carmelo Buttà. Biomed J Sci \& Tech Res

cC) This work is licensed under Creative

Submission Link: https://biomedres.us/submit-manuscript.php

$\begin{array}{ll}\text { BIOMEDICAL } & \text { Assets of Publishing with us } \\ \text { RESEARCHES } & \text { - Global archiving of articles } \\ \text { - Immediate, unrestricted online access }\end{array}$

